OPEN ACCESS

Edited by:

Faik Bilgili,

Erciyes University, Turkey

Reviewed by:

Choong Lyol Lee,

Korea University, South Korea

Sevda Kuşkaya,

Erciyes University, Turkey

Luigi Aldieri,

University of Salerno, Italy

*Correspondence:

Muhammad Fareed

m.fareed@uum.edu.my

Specialty section:

This article was submitted to

Environmental Economics and

Management,

a section of the journal

Frontiers in Environmental Science

Received: 09 July 2021 Accepted: 31 August 2021 Published: 08 October 2021

Citation: Khan $A B$, Fareed $M$, Salameh $A A$ and Hussain H (2021) Financial Innovation, Sustainable Economic Growth, and Credit Risk: A Case of the ASEAN Banking Sector.

Front. Environ. Sci. 9:729922. doi: 10.3389/fenvs.2021.729922

\section{Financial Innovation, Sustainable Economic Growth, and Credit Risk: A Case of the ASEAN Banking Sector}

\author{
Ali Burhan Khan ${ }^{1}$, Muhammad Fareed ${ }^{2 *}$, Anas A. Salameh ${ }^{3}$ and Haroon Hussain ${ }^{4}$ \\ ${ }^{1}$ Department of Management Sciences, National University of Modern Languages, Islamabad, Pakistan, ${ }^{2}$ School of Business \\ Management, Universiti Utara Malaysia, Sintok, Malaysia, ${ }^{3}$ Department of Management Information Systems, College of Business \\ Administration, Prince Sattam Bin Abdulaziz University, Al-Kharj, Saudi Arabia, ${ }^{4}$ Noon Business School, University of Sargodha, \\ Sargodha, Pakistan
}

A dynamic and rapidly changing global financial environment is posing various risks for the banking sector. Therefore, the future of the Association of Southeast Asian Nations (ASEAN) banks depends on how efficiently and effectively they manage these risks. Among these risks, a credit risk is the most crucial risk for the banking sector. Thus, the current study aims to analyze the impact of financial innovation and sustainable economic growth on the credit risk of ASEAN banks. For this purpose, a sample of 4 ASEAN countries from 2011 to 2018 is selected, and by applying a panel-corrected standard error (PCSE) approach, both variables were found to be a significant contributor toward the credit risk. Current research will not only be beneficial for the management of ASEAN countries' banks but also provide help to the overall financial industry and their respective regulatory bodies to understand the behavior of ASEAN banks' credit risk regarding financial innovation and economic growth. Thus, this study will play an essential role concerning the stability of the banking sector in the ASEAN region.

Keywords: Association of Southeast Asian Nations (ASEAN), financial innovation, sustainable economic growth, credit risk, inflation

\section{INTRODUCTION}

During the last few decades, emerging markets, especially the Asian market, are the prime focus of investors and researchers (Megaravalli and Sampagnaro, 2018). One of the prominent markets among Asian markets is the ASEAN market. Its foundation stone was laid on August 8, 1967. Currently, it has ten members named, Brunei Darussalam, Cambodia, Indonesia, Laos, Malaysia, Myanmar, the Philippines, Singapore, Thailand, and Vietnam (Association of Southeast Asian Nations, 2021). ASEAN countries, in the context of the world economy, stand at the most dynamic economic region (Hicklin et al., 1997). In the context of Asia, their economic performance is considered a "miracle" and well investigated by economists and policy-makers from all around the world. ASEAN is the seventh largest economy in the world (Asian Century Institute, 2016), with GDP of \$2.8 trillion (US-ASEAN Business Council, 2021). Despite the fact that ASEAN economies faced turmoil due to the financial crisis between 1997 and 1999 and the global financial crisis (Duong and Huynh, 2020), they still managed to maintain a healthy growth rate. From 2014 to 2019, ASEAN economies grew at a remarkable pace of around 5 percent (ASEAN Stats, 2021). By considering the current pace of the ASEAN economy, it is projected that it is on its path to become the fourth largest economy in the world by 2030 (Australian Government, 2021). 


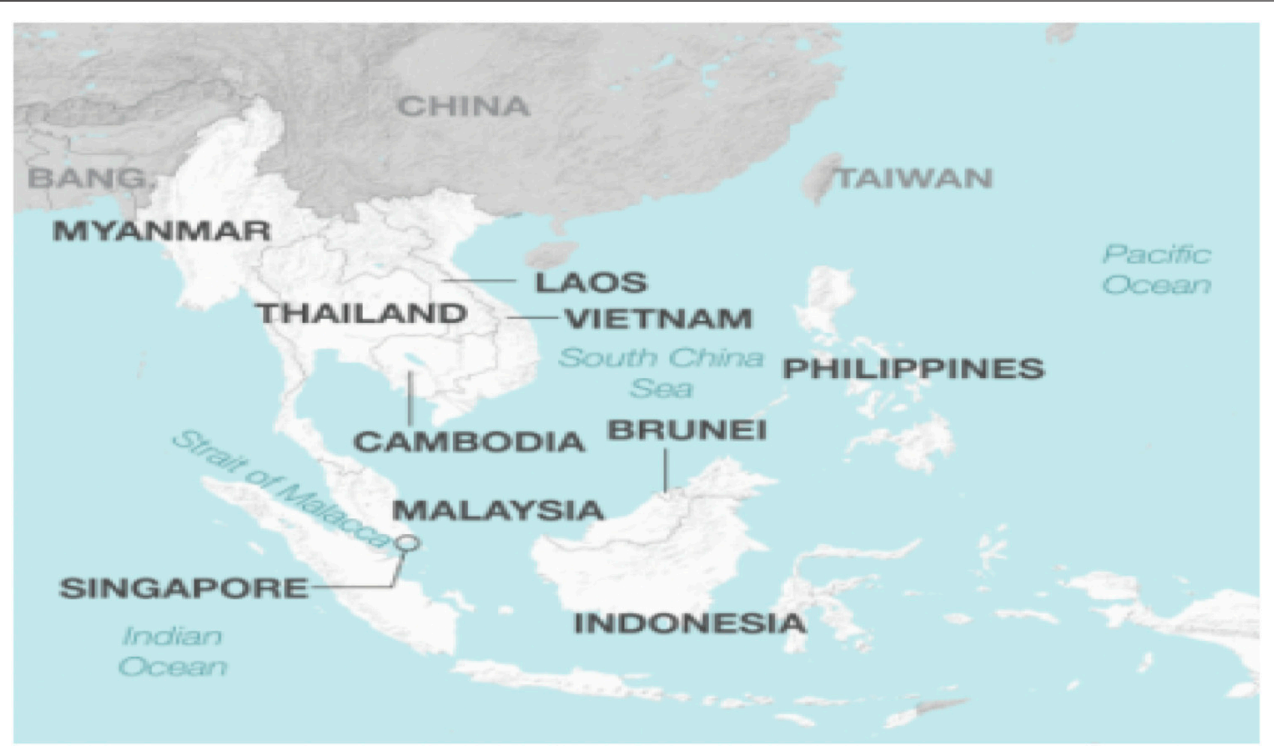

FIGURE 1 | Geographical importance of ASEAN. Source: Stratfor website.

Figure 1 exhibits the geographical importance of the ASEAN region. The ASEAN countries collectively have a population of 650 million people. It is a regional group that brings diverse neighbors together to solve economic, security, and political concerns. It has been a driving force behind Asian economic integration, pushing efforts to establish one of the world's biggest free trade blocs and negotiating six free trade agreements with other Asian economies (Maizland and Albert, 2020).

The emergence of the Asian financial crisis (AFC) in Thailand in July 1997 destabilized the regional economies and made their financial system vulnerable. Particularly, banks' foreign debt increased due to currency devaluation. Meanwhile, investors' savings declined due to loss of confidence, and the fear of bankruptcy prevailed. In these scenarios, the main priority of monetary authorities was to restore the investor's confidence in the economic system and to reduce the fear of collapsing the economic system. At the same time, specific measures were also taken by ASEAN member nations in order to restrict the risktaking behavior of banks and to make the overall restructuring of the banking system. Each member of ASEAN also took emergency measures by introducing blanket guarantees and by introducing strategies to tackle value-impaired assets (Ovi et al., 2014). It was stated by Thoraneenitiyan and Avkiran (2009) that regulatory authorities of each country adopted restructuring strategies because the bank inefficiencies which aroused post the Asian financial crisis (AFC) period were due to countryspecific environments such as a concentrated market, a high interest rate, and economic development.

ASEAN member countries have made a great effort in improving the soundness and efficiency of financial institutions with respect to developing money as well as capital markets (Asian Development Bank, 2013). In the context of the ASEAN region, commercial banks are important and dominant financial institutions (Leon, 2020).
They hold more than 82 percent share in the total financial assets in ASEAN (Asian Development Bank, 2013). However, like global banks, ASEAN banks are also exposed to the credit risk. A credit risk arises due to an increase in bad loans, and these loans are a cause of worry for the banking sector of developed as well as developing countries (Alandejani and Asutay, 2017). Therefore, the determinants of the credit risk have vital significance.

It can be observed from Figure 2 that NPLs of selected ASEAN countries (Indonesia, Malaysia, the Philippines, and Thailand) took a rapid rise from 2014 to 2016 . Having a slight decline from 2016 to 2017, they again increased and reached 2.25 percent in 2019.

Financial innovation is a driving force which pushes an economic system toward higher economic competence in order to align it with economic benefits arising from evolving economic environment (Sekhar, 2013). Financial innovation took a sharp rise during the 1970s and 1980s and changed the world of business (Allen and Gale, 1994). Now, it is a general claim that financial innovation is an integral part of the financial system, and its importance cannot be ignored (Aluko and Ajayi, 2018). It also plays an important role regarding the economic development of a country (Laeven et al., 2015). Having an account of the importance of financial innovation, the banking sector is also substantially increasing its investment in digital enhancements and innovations (Ho et al., 2018). Banks extensively use the information and financial technologies as they already have access to large numbers of data. It helps banks to understand any change arising from the market (Berger, 2003).

Although there are various studies that investigated the determinants of the credit risk, the ASEAN region is still under-investigated in the existing literature. Therefore, the motivation of the current study is to analyze the impact of financial innovation and economic growth, along with macroeconomic (inflation) and firm-specific (size) control 


\section{Ratio of NPLs to total Loans}

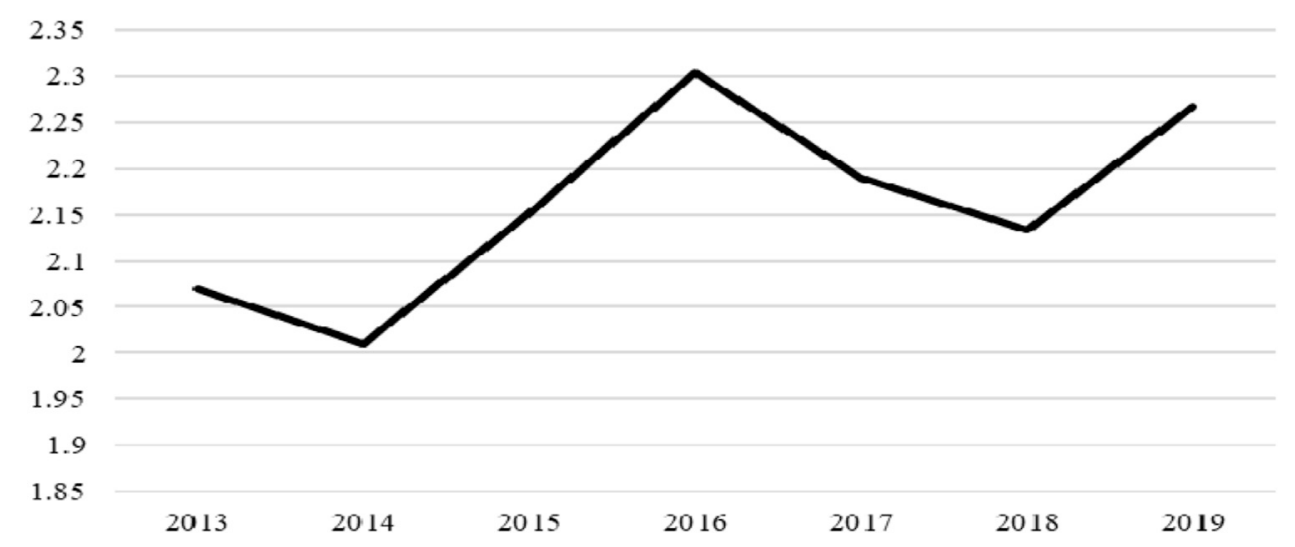

FIGURE 2 | NPLs to the total loan ratio of four ASEAN countries (Indonesia, Malaysia, the Philippines, and Thailand). Source: the World Bank Website.

variables, on the credit risk of ASEAN banks. Additionally, to the best of the authors' knowledge, there is not any study in existing research that analyzed the impact of financial innovation on the credit risk of ASEAN banks. Notwithstanding, the role of economic growth of ASEAN countries regarding the credit risk is still under-researched. With this backdrop, this study attempted to contribute to the existing literature related to determinants of the credit risk of ASEAN countries. Such an attempt is made with an advanced technique named the panelcorrected standard error (PCSE) approach. In doing so, a panel of 4 ASEAN countries (Indonesia, Malaysia, Philippines, and Thailand) is made, which cover the period 2011-2018.

\section{Literature Review}

Understanding the banking sector's financial stability is extremely important, especially in the context of the credit risk (Misman and Bhatti, 2020). As it was stated by Olalere et al. (2020) that a credit risk could significantly influence the value created by ASEAN banks, such importance has substantially increased in these times when the whole financial industry is facing uncertain and hazardous events such as COVID-19 and global financial crisis (GFC) (Misman and Bhatti, 2020). According to $\mathrm{Li}$ and Lin (2021), a credit risk is not only related to an individual firm but also to a systematic risk factor. As a firm's credit risk increases, it may face difficulty paying its debts, which can lead to bankruptcy (Bannier et al., 2021). The topic of a credit risk is getting the attention of many financiers and academicians from developing as we well as developed countries. However, most of the empirical studies, while analyzing the credit risk of banks, considered the developed countries' market (Bonfim, 2009; Louzis et al., 2012) instead of that of developing countries.

A nonperforming loan (NPL) is a category of the loan in which the borrower has defaulted and has failed to make monthly principal and interest payments for a set period of time. In the context of banks, a loan is considered as an NPL when the dueperiod of principal and interest payments reaches 90 days or exceeds it (Baele et al., 2014). An increase in an NPL pushes banks toward lower profit margins. If this scenario persists, it may take the shape of a crisis. The change in an NPL may occur due to the type of borrower, adverse macroeconomic environment, and the policies adopted by banks. To tackle the adverse consequences of NPLs, a comprehensive credit risk management framework is important. In order to establish such a framework, the role of different parties such as researchers, banks' management, and regulators is important. These parties are important stakeholders in efficient credit risk management (Misman and Bhatti, 2020). The rest of the section addresses the key determinants of the credit risk of ASEAN banks which include financial innovation, economic growth, size, and inflation.

\section{Financial Innovation}

Financial innovation plays an important role in an economic system. Economic growth may stop if financiers stop innovation (Laeven et al., 2015). Over the past few decades, there is an increase in financial innovation adaptation among banks. However, the impact of financial innovation on the performance of banks is still a matter of debate as it provides mixed results (Chen and Peng, 2020). Due to the emergence of technology, in the future, banks will have to align themselves with the increased expectations of customers who have become accustomed to seamless customer experiences offered by technology providers. According to the World Economic Forum (2015), the banking sector is going to face the imminent effects of disruption. In the future, disruption will not be a single event but a constant pressure to innovate. It will shape the behavior of customers, business models, and the overall long-standing formation of the financial services sector.

In the 21 st century, the financial innovation topic has become very important due to the serious problems it creates for monetary policy. As the new financial products are introduced, the monetary policy becomes less effective (Odularu and Okunrinboye, 2009). Based on the definition of innovation, such as new products, new product processes, new services, or new organization forms, past studies focused on specific development (Chen and Peng, 2020). However, these 
studies faced the problems of scarred or unavailable data (Arnold and van Ewijk, 2011). In the existing literature, the role of financial innovation is still a matter of debate. According to Merton (1992), there are academicians, financial analysts, and regulatory communities which consider innovation as a giant fad, driven by corporate issuers and institutional investors who expect greater return with less risk. In this case, innovation is fueled by organized exchanges and financial services firms that seek huge profits with multiple activities. According to this point of view, innovation is developed by opportunists whose sole purpose is to superficially differentiate their products. As the innovation goes on, it not only wastes the resources but also feeds the unrealistic expectations of investors. At the same time, issuer could impose larger social cost in the shape of ex ante distortions of investment capital allocation. This phenomenon may create ex post excessive volatility in the capital market in case if the faulty expectations are not fulfilled. It happens in case trading strategies and when financial products failed to deliver promised results. In the context of the banking sector, it was insisted by Instefjord (2005) that financial innovation can increase the risk of banks.

Extensive support to financial innovation is also provided in the existing literature. As stated by Beyani and Kasonde (2009), successful financial innovation results in reduced risk and cost. It is also a source of providing improved service to customers. Similarly, Allen and Carletti (2006) also stated that financial innovation in the shape of introducing new instruments and opening up new markets is desirable because it promotes liquidity and creates diversification opportunities. It was argued by Bhattacharyya and Nanda (2000) that innovating banks could also achieve first-mover advantage against their rival banks.

\section{Economic Growth}

An increase in economic growth, which also goes together with high credit growth, encourages banks to take excessive risk-taking (Bonfim, 2009). It is because banks take high economic growth as a signal of positive market conditions in the future. Thus, if market conditions remain positive in future, banks' performance will increase, and their nonperforming assets could reduce. Incekara and Çetinkaya (2019) study, in the market of Turkey, by applying the panel ordinary least square method and covering the data period 2014 to 2017, found that increase in economic growth decreases the credit risk for Islamic banks. Accordingly, a research by Louzis et al. (2012) concluded that the credit risk in the Greek banking system is explained by economic growth. Their study analyzed the credit risk for each category of the loan, including business loans, consumer loans, and mortgages.

\section{Size}

According to the relationship between the bank size and the credit risk, there are two strands of literature. One strand is based on the "diversification by size" argument (Zribi and Boujelbegrave, 2011). It states that large banks are exposed to less risk due to their better risk diversification capabilities and skills. In addition, large banks also have sufficient risk tolerance (Megginson, 2005). As a result, they can deal effectively with bad loans (Chaibi and Ftiti, 2015).
TABLE 1 | Selected countries and number of banks.

\begin{tabular}{lc}
\hline ASEAN countries & No. of banks \\
\hline Indonesia & 33 \\
Malaysia & 7 \\
Philippines & 12 \\
Thailand & 8 \\
Total & 60
\end{tabular}

On the other hand, large banks normally take the excessive risk under the "too big to fail" assumption (Chaibi and Ftiti, 2015). This assumption can also push a bank toward crisis. According to Stern and Feldman (2004), excessive risk behavior is normally observed in large-size banks because they are not under tight observation by creditors. These banks also enjoy a safety cushion from the government in case of failure. Consequently, these banks increase their leverage as well as loan to "bad" borrowers. This phenomenon leads toward more nonperforming loans.

\section{Inflation}

The impact of inflation on credit risk is ambiguous (Chaibi and Ftiti, 2015). On the one side, inflation can make debt serving easy due to two reasons: first, by decreasing the real value of outstanding loans (Castro, 2013); second, by lowering the unemployment as suggested by Phillips' curve (Nkusu, 2011). On the other side, inflation can also deteriorate the borrowers' debt-serving capacity by lowering their real income (Chaibi and Ftiti, 2015), especially in the case when wages are sticky. In addition, when loans have variable rates, inflation could reduce the loan-servicing capacity of the borrower because lenders will always adjust the rates in order to maintain their real income level. The motive behind adjustment in rates made by the lender is also to shift the burden of increase in the policy rate to the lender. An increase in the policy rate occurs when monetary authorities take action to combat inflation (Nkusu, 2011).

\section{Data and Methodology}

The current study selected the sample of 4 ASEAN countries, including Indonesia, Malaysia, the Philippines, and Thailand. These countries were selected on the basis of data availability. The same sample of ASEAN countries was selected by Leon (2020) in his study while analyzing the impact of macroeconomic variables and the credit risk on the profitability of ASEAN banks. Table 1 shows the countries' names and the number of banks.

The data period selected in this study is the post global financial crisis period from 2011 to 2018. The credit risk measured by nonperforming loans is a dependent variable; financial innovation and economic growth are independent, whereas size and inflation are selected as control variables. Financial innovation may help the banks to reduce the NPL because the banks become able to utilize more information on the borrowers. Furthermore, in such a way, the banks are using a more delicate credit risk analysis tool. Since any precise indicator is not available, therefore, this study 
TABLE 2 | Selected variables and their measurement.

\begin{tabular}{|c|c|c|c|}
\hline Variable & Proxy & Literature support & Source \\
\hline \multicolumn{4}{|c|}{ Dependent Variable } \\
\hline Credit risk (CR) & Ratio of nonperforming loans to total loan & Ozili (2019), Staehr and Uusküla (2021) and Umar and Sun (2018) & $\begin{array}{l}\text { Bloomberg Data } \\
\text { Terminal }\end{array}$ \\
\hline \multicolumn{4}{|c|}{ Independent Variables } \\
\hline $\begin{array}{l}\text { Financial } \\
\text { innovation (FI) } \\
\text { Economic } \\
\text { growth (EG) }\end{array}$ & $\begin{array}{l}\text { Ratio of broad money to narrow money } \\
\text { (M2/M1) } \\
\text { GDP growth (annual \%) }\end{array}$ & $\begin{array}{l}\text { Nazir et al. (2018), Qamruzzaman and Jianguo (2017) and Bara and } \\
\text { Mudzingiri (2016) } \\
\text { Staehr and Uusküla (2021) and Umar and Sun (2018) }\end{array}$ & $\begin{array}{l}\text { Bloomberg Data } \\
\text { Terminal } \\
\text { Bloomberg Data } \\
\text { Terminal }\end{array}$ \\
\hline \multicolumn{4}{|c|}{ Control Variables } \\
\hline Size (SIZ) & Natural log of total assets & İncekara and Çetinkaya (2019) and Curak et al. (2013) & $\begin{array}{l}\text { Bloomberg Data } \\
\text { Terminal }\end{array}$ \\
\hline Inflation (INF) & Consumer Prices Index (CPI) & Staehr and Uusküla (2021) and Kepli et al. (2021) & $\begin{array}{l}\text { Bloomberg Data } \\
\text { Terminal }\end{array}$ \\
\hline
\end{tabular}

follows the prior studies such as Nazir et al. (2018), Qamruzzaman and Jianguo (2017) and Bara and Mudzingiri (2016), and uses the M2/M1 ratio as a substitute for financial innovation. The data are in the shape of a balanced panel where each variable consists of 480 observations. The summary of selected variables, their measurement, and literature support is provided in Table 2.

To empirically analyze the relationship between the credit risk and financial innovation, economic growth, size, and inflation, the panel data analysis technique is adopted due to its control on serial correlation (Neagu and Teodoru, 2019; Shahzad et al., 2021) and heterogeneity (Baltagi, 2005).

$$
C R_{i t}=f\left(F I_{i t}+E G_{i t}+S I Z_{i t}+I N F_{i t}\right) .
$$

Taking credit risk as a dependent variable, the estimation model is formed as follow:

$$
C R_{i t}=a+\beta_{1} F I_{i t}+\beta_{2} E G_{i t}+\beta_{3} S I Z_{i t}+\beta_{4} I N F_{i t}+\varepsilon_{t} .
$$

In Eq. 2, $i$ represents the country, $t$ stands for the time, and CR, FI, EG, SIZ, and INF represent the credit risk, financial innovation, economic growth, size, and inflation, respectively. The empirical investigation is done with the help of the panel-corrected standard error (PCSE) approach. The PCSE approach was proposed by Beck and Katz (1995) in terms of cross-sectional and time dimensions. It is the most robust technique to deal with the problem of autocorrelation and heteroscedasticity. Table I of Appendix A shows the existence of autocorrelation in our model. Therefore, this problem is overcome with the help of the PCSE technique. It was stated by Ikpesu et al. (2019) that PCSE is autocorrelation-free, less susceptible to outliers, and gives precise standard error estimates. As in our study, $\mathrm{N}$ is greater than $\mathrm{T}$ (number of banks is more than years), and the most appropriate estimator is the panel-corrected standard error (PCSE) (Marques et al., 2016).

\section{RESULTS AND INTERPRETATIONS}

The descriptive statistics of the study are reported in Table 3. According to the results, the mean value of the credit risk,

\begin{tabular}{lccccc}
\hline \multicolumn{2}{l}{ TABLE 3 } & Descriptive statistics. & & & \\
Variable & Observations & Mean & Std. Dev. & Min & Max \\
\hline $\mathrm{CR}$ & 480 & 4.164 & 4.828 & 0.063 & 60.090 \\
$\mathrm{FI}$ & 480 & 3.783 & 0.557 & 2.849 & 4.694 \\
$\mathrm{EG}$ & 480 & 5.263 & 1.248 & 0.840 & 7.242 \\
$\mathrm{SIZ}$ & 480 & 18 & 34.2 & 0.001 & 195 \\
$\mathrm{INF}$ & 480 & 3.778 & 1.863 & -0.900 & 6.412
\end{tabular}

measured through NPLs, is 4.164 percent, with the minimum and maximum values of 0.063 and 60.090 , respectively. It exhibits a high standard deviation of 4.828. It is because the nonperforming loans of selected ASEAN countries exhibited a sharp rise from 2014 to 2016 by reaching 2.3 percent from 2 percent. Such high standard deviation was due to the change in the external and internal environment of selected ASEAN countries. It was reported by Purwono et al. (2020) that Malaysia is the country most exposed to the external environment. However, Thailand's NPLs are primarily influenced by the local environment. Financial innovation has a mean value of 3.783 percent with a lowest standard deviation of 0.557 percent. The lowest standard deviation is a result of the stable monetary policy adopted by the regulatory authorities of ASEAN nations.

Economic growth has a maximum and minimum value of 7.242 percent and 0.840 percent, respectively. It has a moderate standard deviation of 1.248. ASEAN countries enjoyed a remarkable growth rate of around 5 percent from 2014 to 2019 .

The inflation rate has a mean value of 3.778 , with a standard deviation of 1.863. The ASEAN countries are more dependent on external causes for inflation, and inflation is a byproduct of their openness in trade. It has also been discovered that supply shock and monetary shock are the major drivers of inflation in Asia, with demand-pull inflation playing a minor role (Edward and Ramayah, 2016). According to Osorio and Unsal (2013), commodity prices have a preeminent role in generating inflation in ASEAN nations other than Indonesia, possibly due to the openness of these economies and their reliance on oil and food imports. However, because the region's influence on global 
TABLE 4 | Correlation results.

\begin{tabular}{lcccc}
\hline Variable & FI & EG & SIZ & INF \\
\hline FI & 1 & & & \\
EG & 0.020 & 1 & 1 & \\
SIZ & -0.294 & -0.216 & -0.542 & 1 \\
INF & 0.521 & 0.1571 & & \\
\hline
\end{tabular}

commodity prices has grown, part of the contribution from global commodity prices may be traced back to regional demand trends. Among all selected variables, size shows the highest standard deviation of 34.2. It is because the difference in the asset size among ASEAN banks is widespread (Mongid, 2016).

Table 4 exhibits the correlation results. The highest negative correlation of 0.542 is observed among size and inflation. Whereas, a minimal level of correlation (0.020) was exhibited by financial innovation and economic growth. Considering overall results of correlation, the value among selected variables fall within the accepted range of 0.90 set by Pallant (2007).

Before applying the PCSE technique, several diagnostics tests such as autocorrelation, heteroscedasticity, and unit-root were applied. The results of these tests are reported in Tables I-III of Appendix A, respectively. An autocorrelation problem was found in the model. Therefore, the PCSE technique was adopted, which is robust for autocorrelation and heteroscedasticity. According to the unit-root test results, all series are stationary at the level. The empirical findings of the PCSE approach are reported in Table 5.

The estimation results of the panel-corrected standard error (PCSE) approach are reported in Table 5. The results indicated that financial innovation and sustainable economic growth has a significant relationship with the credit risk of ASEAN banks. The coefficient of these relationships is negative, which means an increase in both financial innovation and sustainable economic growth results in decreased credit risk.

The significant and negative impact of financial innovation on the credit risk is reported in this study. It is because financial innovation reduces the risk and transaction cost by deepening, widening, and integrating the capital markets (Hachicha, 2008). Accordingly, it was stated by Li et al. (2016) that emerging techniques such as artificial intelligence have been applied these days to evaluate the credit risk. These technologies are a result of improvement in computation and information technology (K. Li et al., 2016). As it was stated by Merton (1992), financial innovation does not operate in a vacuum and surrounding regulatory, and institutional quality plays an important role in defining it; by considering this point of view, it can be inferred, based on the results of this study, that regulatory and institutional quality of ASEAN countries is encouraging for banks to innovate, which is resulting in their reduced credit risk. The implications of Norden et al. (2014) study in the US market, which suggested that financial innovation is beneficial for risk management, also proved true for the ASEAN market according to the results of this study.

According to the results, sustainable economic growth has a negative coefficient sign. It indicates that as the economic growth
TABLE 5 | Estimation results regarding impact of financial innovation, economic growth, size, and inflation on the credit risk.

\begin{tabular}{lccc} 
Variable & Coefficient & Standard error & $\boldsymbol{p}$-value \\
\hline C & 11.753 & 1.891 & 0 \\
FI & $-0.666^{b}$ & 0.349 & 0.018 \\
EG & $-0.388^{\mathrm{b}}$ & 0.169 & 0.022 \\
SIZ & $-0.180^{\mathrm{b}}$ & 0.079 & 0.023 \\
INF & -0.139 & 0.283 & 0.622 \\
\hline R-squared & 0.0221 & & \\
Wald chi2 (4) & 26.59 & & \\
Prob > chi2 & 0 & & \\
Number of observations & 480 & & \\
Number of groups & 60 & &
\end{tabular}

aSignificant at the 0.1 level.

${ }^{\mathrm{b}}$ Significant at the 0.05 level.

'Significant at the 0.01 level.

will increase, the credit risk of ASEAN banks will decrease. These results reflect the claim of Bonfim (2009) that during the high economic growth times, which are also accompanied by the high credit growth, banks may lean toward excessive risk-taking, considering some positive expectations about the market. Similarly, in the context of developed countries, including Italy, Greece, and Spain, the same findings were reported by Messai and Jouini (2013) study. Inline, the study by Curak et al. (2013) of 10 European countries also found a decline in the credit risk with the increase in economic growth.

In the context of control variables, the negative impact of the size on the credit risk can be attributed to the "increasing returns to scale in information processing" perspective provided by Louzis et al. (2012). It indicates that as the size of ASEAN banks increases, they will have more resources to collect information; consequently, their credit risk will reduce. In the light of results, ASEAN banks are also attaining the "diversification by size" benefit proposed by Zribi and Boujelbegrave (2011).

\section{ROBUSTNESS CHECKS}

We also employed some additional tests such as 2-step system GMM and Driscoll-Kraay standard error regression to check the robustness of the results.

Among panel data methods, system GMM is better because it is robust for endogeneity, autocorrelation, and unobserved heterogeneity (Akhtar et al., 2021; Alqahtani and Mayes, 2018; Dahir et al., 2018). Furthermore, for the samples where $\mathrm{T}$ (number of years) is less than $\mathrm{N}$ (number of cross sections), GMM is a popular method. Since this is also the case with our study, GMM is also applied to the sample. As post estimation tests of system GMM, the Hansen/Sargan test for overidentification restriction and the AR test for serial correlation were also applied. The value of the Sargan test in Table 6 shows instrument validity and that the model is correctly specified. Moreover, the test of serial correlation should indicate the existence of first-order correlation $[\mathrm{AR}(1)]$ and simultaneously preclude the existence of second-order [AR (2)] correlation (Dahir et al., 2018). The 
TABLE 6 | Generalized method of movements (2-Step System GMM) regression results.

\begin{tabular}{lccc}
\hline Variable & Coefficient & Standard error & $\boldsymbol{p}$-value \\
\hline L1 CR & 0.1716 & 0.0095 & 0 \\
C & $20.5156^{\mathrm{c}}$ & 2.7680 & 0 \\
FI & $-1.9145^{\mathrm{c}}$ & 0.3735 & 0 \\
EG & $-0.3168^{\mathrm{b}}$ & 0.1266 & 0.012 \\
SIZ & $-0.5699^{\mathrm{c}}$ & 0.1133 & 0 \\
INF & $-0.1105^{\mathrm{b}}$ & 0.0536 & 0.039 \\
\hline Groups & & 60 & \\
Instruments & & 32 & \\
AR (2) & & 1.1781 & \\
Sargan test & & 37.3532 & \\
Prob > chi & & 0.0694 &
\end{tabular}

aSignificant at the 0.1 level.

${ }^{b}$ Significant at the 0.05 level.

'Significant at the 0.01 level.

results of system GMM reported in Table 6 confirm the findings obtained by using PCSE regression. Also, the findings are more robust and the significance level is improved.

The results shown in Table 7 are obtained by an ordinary least squares (OLS) regression method with robust standard errors developed by Driscoll and Kraay, 1998. This method is robust for the data which have heteroscedasticity. Also, this method is robust against series correlation and cross-dependence. This method is reliable when the time dimension is less than the cross sections (Topcu and Gulal, 2020). These results provide further evidence for the main results of this study and confirm that the results reported in Table 5 are robust.

\section{CONCLUSION}

Identification of credit risk determinants is a key issue for the regulatory and monetary authorities concerned with the bank' management and financial stability. Considering the vital importance of the credit risk, the current study analyzed the impact of financial innovation and economic growth on the credit risk of banks licensed to operate in four ASEAN countries, namely, Indonesia, Malaysia, the Philippines, and Thailand. The outcome of the panel-corrected standard error (PCSE) approach indicated that financial innovation and economic growth are significant determinants of the credit risk. Besides, size is also proved to be favorable for the management of the credit risk in ASEAN banks.

Financial innovation has made the banking system easier in economic activities. It lowers transaction costs for the financial system by providing better financial services and accelerates the process of capital accumulation by encouraging the propensity to save in society, which ultimately drives economic progress. When formulating financial policy, policy-makers should pay great attention to the fact that financial innovations in the financial system can be adopted and positively impact the economy. The monetary authorities of ASEAN nations should encourage financial innovation by increasing money supply as financial innovation is proven to be suitable for the credit risk of the ASEAN banks. Accelerated economic growth, which is also
TABLE 7 | Driscoll-Kraay standard error regression results.

\begin{tabular}{lccc}
\hline Variable & Coefficient & Drisc/Kraay standard error & $\boldsymbol{p}$-value \\
\hline $\mathrm{C}$ & 11.753 & 1.9687 & 0.001 \\
$\mathrm{FI}$ & $-0.6668^{\mathrm{C}}$ & 0.1814 & 0.008 \\
$\mathrm{EG}$ & $-0.3882^{\mathrm{b}}$ & 0.1299 & 0.020 \\
$\mathrm{SIZ}$ & $-0.1806^{\mathrm{a}}$ & 0.0906 & 0.087 \\
$\mathrm{INF}$ & -0.1396 & 0.0780 & 0.117 \\
\hline aSignificant at the 0.1 level. & & \\
'SSignificant at the 0.05 level. & & \\
'Significant at the 0.01 level. & &
\end{tabular}

accompanied by strong credit growth, is encouraging banks to take an undue risk. Because banks see high economic growth as a sign of positive market conditions in the future, so if future market conditions remain positive, banks will perform better, and their distressed assets may decline. The results of this study also show that economic growth lowers the credit risk. As positive economic growth makes banks more optimistic, banks become more vulnerable to the credit risk. The governments needs to develop regulations that can prevent banks from taking excessive risk.

In terms of ASEAN bank's management, notwithstanding maintaining a healthy level of size, it is recommended that they should keep track of economic growth before taking any bankspecific decision. Large banks can diversify their risk, and the credit risk decreases with the size of the bank. Bank diversification takes several forms, most of which are generally related to the asset size. Compared to small institutions, large banks have access to a wider variety of borrowers and a base for brokerage. Large banks deal with a wider geographic area. Likewise, the portfolio of large banks is more diversified due to a wider mix of customers from different industries. Furthermore, they are equipped in terms of people with more specialized experience. Large banks are generally more active than smaller institutions in the secondary credit market. In addition, large banks generally have more sophisticated risk management systems than smaller banks. Our analysis has several interesting policy implications. The first concerns the security and soundness of the banking system. While the bank size is positively related to diversification, this relationship occurs because large banks have a lower companyspecific risk and large institutions have a higher systematic risk. Demsetz and Strahan (1997) considered this somewhat worrying from the perspective of the security and soundness of the banking system. Business-specific risk mitigation is certainly an advantage, but its benefit is primarily realized by individual institutions.

Inflation is directly linked to the price stability in any country, which drives down the capacity of the borrowers to pay back their interest and principal amounts of loan. Inflation shows the monetary policy that is being adopted by the country. In a policy where price stability is low and lending rates are increasing, the borrowers may not be able to meet their debt obligations. Given that, inflation, in general, should increase the NPLs. High inflation increases the interest rates and decreases the repayment capacity of individuals and institutions. On the other side, inflation may also have a negative relationship with the NPLs 
because of a decrease in the real value of outstanding debts and unemployment. However, the results of this study do not support either of these hypotheses and are statistically insignificant. These results are consistent with the past studies such as the findings of Koju et al. (2019) Lee et al. (2019) and Tanasković and Jandrić (2015). Regarding limitation of current research, it was limited to four ASEAN countries due to data availability issues. Such limitation was also faced by the study by Leon (2020).

In addition, the data period of this study was limited to 2011 to 2018 due to data availability issues. In terms of future recommendations, the current research model can be extended to other geographical regions such as South Asia and Gulf countries.

\section{REFERENCES}

Akhtar, S., Hussain, H., and Hussain, R. Y. (2021). Contributing role of regulatory compliance and Islamic operations in bank risk: evidence from Pakistan. Nankai Business Rev. Int. doi:10.1108/nbri-07-2020-0037

Alandejani, M., and Asutay, M. (2017). Nonperforming loans in the GCC banking sectors: Does the Islamic finance matter? Res. Int. Business Finance 42, 832-854. doi:10.1016/j.ribaf.2017.07.020

Allen, F., and Carletti, E. (2006). Credit risk transfer and contagion. J. Monetary Econ. 53 (1), 89-111. doi:10.1016/j.jmoneco.2005.10.004

Allen, F., and Gale, D. (1994). Financial Innovation and Risk Sharing. Massachusetts: MIT Press.

Alqahtani, F., and Mayes, D. G. (2018). Financial stability of Islamic banking and the global financial crisis: evidence from the Gulf cooperation council. Econ. Syst. 42 (2), 346-360. doi:10.1016/j.ecosys.2017.09.001

Aluko, O. A., and Ajayi, M. A. (2018). Determinants of banking sector development: Evidence from Sub-Saharan African countries. Borsa Istanbul Rev. 18 (2), 122-139. doi:10.1016/j.bir.2017.11.002

Arnold, I. J. M., and van Ewijk, S. E. (2011). Can pure play internet banking survive the credit crisis? J. Banking Finance 35 (4), 783-793. doi:10.1016/ j.jbankfin.2010.10.010

ASEAN Stats (2021). Growth of the gross domestic product (GDP) in ASEAN. https://data.aseanstats.org/indicator/AST.STC.TBL.6.

Asian Century Institute (2016). Why ASEAN matters. https://asiancenturyinstitute. com/international/1207-why-asean-matters.

Asian Development Bank (2013). The road to Asean financial integration. https:// www.adb.org/sites/default/files/publication/30202/road-asean-financialintegration.pdf.

Association of Southeast Asian Nations (2021). About ASEAN. https://asean.org/ asean/about-asean/.

Australian Government (2021). ASEAN's economic growth outpaces the rest of the world. https://www.austrade.gov.au/asean-now/why-asean-matters-toaustralia/asean-economic-growth/.

Baele, L., Farooq, M., and Ongena, S. (2014). Of religion and redemption: Evidence from default on Islamic loans. J. Banking Finance 44, 141-159. doi:10.1016/ j.jbankfin.2014.03.005

Baltagi, B. H. (2005). Econometric analysis of panel data. West Sussex, UK: John Wiley \& Sons.

Bannier, C. E., Bofinger, Y., and Rock, B. (2021). Corporate social responsibility and credit risk. Finance Res. Lett., 102052. doi:10.1016/ j.frl.2021.102052

Bara, A., and Mudzingiri, C. (2016). Financial innovation and economic growth: evidence from Zimbabwe. Investment Manag. financial Innov. 13 (2), 65-75. doi:10.21511/imfi.13(2).2016.07

Beck, N., and Katz, J. N. (1995). What to do (and not to do) with time-series crosssection data. Am. Polit. Sci. Rev. 89 (3), 634-647. doi:10.2307/2082979

Berger, A. N. (2003). The economic effects of technological progress: Evidence from the banking industry. J. Money, Credit, Banking 35 (2), 141-176. doi:10.1353/mcb.2003.0009

\section{DATA AVAILABILITY STATEMENT}

The original contributions presented in the study are included in the article/Supplementary Material; further inquiries can be directed to the corresponding author.

\section{AUTHOR CONTRIBUTIONS}

AK: literature review and write up. MF: discussion and article drafting. AS: data collection and analysis. HH: robust analysis and results discussion.

Beyani, M., and Kasonde, R. (2009). Financial innovation and the importance of modern risk management systems-a case of Zambia. IFC Bulletins Chapters 31, 283-293.

Bhattacharyya, S., and Nanda, V. (2000). Client discretion, switching costs, and financial innovation. Rev. Financ. Stud. 13 (4), 1101-1127. doi:10.1093/rfs/ 13.4.1101

Bonfim, D. (2009). Credit risk drivers: Evaluating the contribution of firm level information and of macroeconomic dynamics. J. Banking Finance 33 (2), 281-299. doi:10.1016/j.jbankfin.2008.08.006

Castro, V. (2013). Macroeconomic determinants of the credit risk in the banking system: The case of the GIPSI. Econ. Model. 31, 672-683. doi:10.1016/ j.econmod.2013.01.027

Chaibi, H., and Ftiti, Z. (2015). Credit risk determinants: Evidence from a crosscountry study. Res. Int. Business Finance 33, 1-16. doi:10.1016/ j.ribaf.2014.06.001

Chen, T.-H., and Peng, J.-L. (2020). Statistical and bibliometric analysis of financial innovation. Libr. Hi Tech 38 (2), 308-319. doi:10.1108/lht-11-2017-0232

Curak, M., Pepur, S., and Poposki, K. (2013). Determinants of non-performing loans-evidence from Southeastern European banking systems. Banks Bank Syst. 8 (1), 45-53.

Dahir, A. M., Mahat, F. B., and Ali, N. A. B. (2018). Funding liquidity risk and bank risk-taking in BRICS countries. Ijoem 13 (1), 231-248. doi:10.1108/ijoem-032017-0086

Demsetz, R. S., and Strahan, P. E. (1997). Diversification, size, and risk at bank holding companies. J. Money, Credit Banking 29 (3), 300-313. doi:10.2307/ 2953695

Driscoll, J. C., and Kraay, A. C. (1998). Consistent covariance matrix estimation with spatially dependent panel data. Rev. Econ. Stat. 80 (4), 549-560. doi:10.1162/003465398557825

Duong, D., and Huynh, T. L. D. (2020). Tail dependence in emerging ASEAN-6 equity markets: empirical evidence from quantitative approaches. Financial Innovation 6 (1), 1-26. doi:10.1186/s40854-019-0168-7

Edward, T., and Ramayah, M. (2016). The Determinants of Inflation: an ASEAN perspective. Taylor's Business Rev. 6 (1), 49-72.

Hachicha, A. (2008). Does financial innovation of credit derivatives make bank riskier? J. Econ. Manag. Perspect. 2 (1), 1.

Hicklin, J., Robinson, D., and Singh, A. (1997). Macroeconomic issues facing ASEAN countries. https://www.imf.org/external/pubs/nft/macro/ overview.htm

Ho, C.-Y., Huang, S., Shi, H., and Wu, J. (2018). Financial deepening and innovation: The role of political institutions. World Dev. 109, 1-13. doi:10.1016/j.worlddev.2018.02.022

Ikpesu, F., Vincent, O., and Dakare, O. (2019). Growth effect of trade and investment in Sub-Saharan Africa countries: Empirical insight from panel corrected standard error (PCSE) technique. Cogent Econ. Finance. doi:10.1080/23322039.2019.1607127

Instefjord, N. (2005). Risk and hedging: Do credit derivatives increase bank risk? J. Banking Finance 29 (2), 333-345. doi:10.1016/j.jbankfin.2004.05.008

İncekara, A., and Çetinkaya, H. (2019). Credit risk management: A panel data analysis on the Islamic banks in Turkey. Proced. Comp. Sci. 158, 947-954. 
Kepli, S., Bani, Y., Rosland, A., and Laila, N. (2021). Non-Performing Loans and Macroeconomic Variables in Malaysia: Recent Evidence. Int. J. Econ. Manag. 15 (1), 19-31.

Koju, L., Koju, R., and Wang, S. (2019). Macroeconomic determinants of credit risks: evidence from high-income countries. Ejmbe 29 (1), 41-53. doi:10.1108/ ejmbe-02-2018-0032

Laeven, L., Levine, R., and Michalopoulos, S. (2015). Financial innovation and endogenous Growth. J. Financial Intermediation 24 (1), 1-24. doi:10.1016/ j.jfi.2014.04.001

Lee, Y. Y., Dato Haji Yahya, M. H., Habibullah, M. S., and Mohd Ashhari, Z. (2019). Non-performing loans in European Union: country governance dimensions. Jfep 12 (2), 209-226. doi:10.1108/jfep-01-2019-0027

Li, K., Niskanen, J., Kolehmainen, M., and Niskanen, M. (2016). Financial innovation: Credit default hybrid model for SME lending. Expert Syst. Appl. 61, 343-355. doi:10.1016/j.eswa.2016.05.029

Li, T., and Lin, H. (2021). Credit risk and equity returns in China. Int. Rev. Econ. Finance 76, 588-613. doi:10.1016/j.iref.2021.07.002

Louzis, D. P., Vouldis, A. T., and Metaxas, V. L. (2012). Macroeconomic and bankspecific determinants of non-performing loans in Greece: A comparative study of mortgage, business and consumer loan portfolios. J. Banking Finance 36 (4), 1012-1027. doi:10.1016/j.jbankfin.2011.10.012

Maizland, L., and Albert, E. (2020). What Is ASEAN? https://www.cfr.org/ backgrounder/what-asean.

Marques, A. C., Fuinhas, J. A., and Gaspar, J. d. S. (2016). On the Nexus of Energy Use - Economic Development: A Panel Approach. Energ. Proced. 106, 225-234. doi:10.1016/j.egypro.2016.12.118

Megaravalli, A. V., and Sampagnaro, G. (2018). Macroeconomic indicators and their impact on stock markets in ASIAN 3: A pooled mean group approach. Cogent Econ. Finance 6 (1), 1432450. doi:10.1080/23322039.2018.1432450

Megginson, W. L. (2005). The economics of bank privatization. J. Banking Finance 29 (8-9), 1931-1980. doi:10.1016/j.jbankfin.2005.03.005

Merton, R. C. (1992). Financial innovation and economic performance. J. Appl. Corporate Finance 4 (4), 12-22. doi:10.1111/j.1745-6622.1992.tb00214.x

Messai, A. S., and Jouini, F. (2013). Micro and macro determinants of non-performing loans. Int. J. Econ. Financial Issues 3 (4), 852. doi:10.14706/jecoss11312

Misman, F. N., and Bhatti, M. I. (2020). The determinants of credit risk: An evidence from ASEAN and GCC Islamic Banks. Jrfm 13 (5), 89. doi:10.3390/ jrfm13050089

Mongid, A. (2016). Business efficiency of the commercial banks in ASEAN. Investment Manag. Financial Innov. 13 (1), 67-76. doi:10.21511/imfi.13(1).2016.06

Nazir, M. R., Tan, Y., and Nazir, M. I. (2018). Financial innovation and economic growth: Empirical evidence from China, India and Pakistan. Int. J. Finance Econ.

Neagu, O., and Teodoru, M. (2019). The relationship between economic complexity, energy consumption structure and greenhouse gas emission: Heterogeneous panel evidence from the EU countries. Sustainability 11 (2), 497. doi:10.3390/su11020497

Nkusu, M. (2011). Nonperforming loans and macrofinancial vulnerabilities in advanced economies (WP/11/161). Washington: IMF Publications.

Norden, L., Silva Buston, C., and Wagner, W. (2014). Financial innovation and bank behavior: Evidence from credit markets. J. Econ. Dyn. Control. 43, 130-145. doi:10.1016/j.jedc.2014.01.015

Odularu, G. O., and Okunrinboye, O. A. (2009). Modeling the impact of financial innovation on the demand for money in Nigeria. Afr. J. Business Manag. 3 (2), $39-51$.

Olalere, O., Aminul Islam, M., Zukime Mat Junoh, M., Sallha Yusoff, W., and Masum Iqbal, M. (2020). Revisiting the impact of intrinsic financial risks on the firm value of banks in ASEAN-5 countries: a panel data approach. Banks Bank Syst. 15 (2), 200-213. doi:10.21511/bbs.15(2).2020.18

Osorio, C., and Unsal, D. F. (2013). Inflation dynamics in Asia: Causes, changes, and spillovers from China. J. Asian Econ. 24, 26-40. doi:10.1016/ j.asieco.2012.10.007
Ovi, N. Z., Perera, S., and Colombage, S. (2014). Market power, credit risk, revenue diversification and bank stability in selected ASEAN countries. South East Asia Res. 22 (3), 399-416. doi:10.5367/sear.2014.0221

Ozili, P. K. (2019). Non-performing loans and financial development: new evidence. Jrf 20 (1), 59-81. doi:10.1108/jrf-07-2017-0112

Pallant, J. (2007). SPSS survival manual. New York: McGraw-Hill Education.

Purwono, R., Tamtelahitu, J., Tamtelahitu, J., and Mubin, M. K. (2020). The Effect of Exchange Rates and Interest Rates of Four Large Economies on the Health of Banks in ASEAN-3. Jafeb 7 (10), 591-599. doi:10.13106/jafeb.2020.vol7.no10.591

Qamruzzaman, M., and Jianguo, W. (2017). Financial innovation and economic growth in Bangladesh. Financial Innovation 3 (1), 1-24. doi:10.1186/s40854017-0070-0

Satya Sekhar, G. V. (2013). Theorems and Theories of Financial Innovation: Models and Mechanism Perspective. Financial Quantitative Anal. 1 (2), 26. doi:10.12966/fqa.05.02.2013

Shahzad, U., Doğan, B., Sinha, A., and Fareed, Z. (2021). Does export product diversification help to reduce energy demand: Exploring the contextual evidences from the newly industrialized countries. Energy 214, 118881. doi:10.1016/j.energy.2020.118881

Staehr, K., and Uusküla, L. (2021). Macroeconomic and macro-financial factors as leading indicators of non-performing loans. Jes 48 (3), 720-740. doi:10.1108/ jes-03-2019-0107

Stern, G. H., and Feldman, R. J. (2004). Too Big to Fail: The Hazards of Bank Bailouts. Washington, DC: The Brookings Institution.

Thoraneenitiyan, N., and Avkiran, N. K. (2009). Measuring the impact of restructuring and country-specific factors on the efficiency of post-crisis East Asian banking systems: Integrating DEA with SFA. Socio-Economic Plann. Sci. 43 (4), 240-252. doi:10.1016/j.seps.2008.12.002

Topcu, M., and Gulal, O. S. (2020). The impact of COVID-19 on emerging stock markets. Finance Res. Lett. 36, 101691. doi:10.1016/j.frl.2020.101691

Umar, M., and Sun, G. (2018). Determinants of non-performing loans in Chinese banks. Jabs 12 (3), 273-289. doi:10.1108/jabs-01-2016-0005

US-ASEAN Business Council (2021). ASEAN's Economy. https://www.usasean. org/why-asean/asean-economy.

V. De Leon, M. (2020). The impact of credit risk and macroeconomic factors on profitability: the case of the ASEAN banks. Banks Bank Syst. 15 (1), 21-29. doi:10.21511/bbs.15(1).2020.03

World Economic Forum (2015). The future of financial services - how disruptive innovations are reshaping the way financial services are structured, provisioned and consumed. http://www3.weforum.org/docs/WEF_The_future_of_ financial_services.pdf.

Zribi, N., and Boujelbegrave, Y. (2011). The factors influencing bank credit risk: The case of Tunisia. J. Account. Taxation 3 (4), 70-78.

Conflict of Interest: The authors declare that the research was conducted in the absence of any commercial or financial relationships that could be construed as a potential conflict of interest.

Publisher's Note: All claims expressed in this article are solely those of the authors and do not necessarily represent those of their affiliated organizations, or those of the publisher, the editors, and the reviewers. Any product that may be evaluated in this article, or claim that may be made by its manufacturer, is not guaranteed or endorsed by the publisher.

Copyright (c) 2021 Khan, Fareed, Salameh and Hussain. This is an open-access article distributed under the terms of the Creative Commons Attribution License (CC BY). The use, distribution or reproduction in other forums is permitted, provided the original author(s) and the copyright owner(s) are credited and that the original publication in this journal is cited, in accordance with accepted academic practice. No use, distribution or reproduction is permitted which does not comply with these terms. 


\section{APPENDIX A}

TABLE I | Autocorrelation test results for selected variables.

F-statistic $\quad 18.6455$

Obs. ${ }^{*}$ R-squared $\quad 35.0774$

Prob. F $(2,473)$

Prob. chi-square (2)

TABLE II | Heteroscedasticity test results for selected variables.

\section{F-statistic}

1.3111

Obs. ${ }^{*}$ R-squared

5.2418

Prob. F $(4,475)$

0.2648

Prob. chi-square (4)

0.2634

TABLE III | Panel unit root test results.

Variables
Levin, Lin, and chu

T-Statistics

$-63.5578$

$-33.0134$

$-34.5279$

$-8.3305$

$-4.9804$
Results

Level

$p$-value

0

Stationary

Stationary

Stationary

Stationary

Stationary 